Dialectologia 28 (2022), 57-80.

ISSN: 2013-2247

Received 23 January 2020.

Accepted 20 April 2020.

\title{
VERBAL NEGATION STRATEGIES IN THE BLACK COUNTRY- SPATIAL AND TEMPORAL VARIATION
}

\author{
Esther ASPREY* \\ University of Wolverhampton \\ E.Asprey3@wlv.ac.uk
}

\begin{abstract}
This paper examines data from the traditional language variety of the Black Country area of the west Midlands of England; an area lying directly to the west of the city of Birmingham. I introduce the strategies which have been used over time to mark negation of modal and auxiliary verbs in Black Country English, drawing on historical and present-day sources and to inform this introduction. I then outline the phonological rules which have governed the two main competing strategies, one of which continues to govern the present-day localised system of negation. I next examine the rise of one strategy over the other and discuss the timeframe in which this might have occurred, using both dialect surveys and literary sources to strengthen my case. I finally examine the sociolinguistic stratification of the local negative forms, and their sociolinguistic significance within the modern speech community. For this last section I draw on a modern corpus of 39 Black Country residents which was collected between 2003 and 2006.
\end{abstract}

Keywords: verbal negation, ablaut mutation, Midlands English, dialect contact, historical linguistics

ESTRATÈGIES DE NEGACIÓ VERBAL EN EL “BLACK COUNTRY” - VARIACIÓ ESPACIAL I TEMPORAL Resum

Aquest article examina dades de la varietat de llengua tradicional de l'àrea Black Country de West Midlands d'Anglaterra; una àrea que es troba directament a l'oest de la ciutat de Birmingham. Es presenten les estratègies que s'han utilitzat al llarg del temps per marcar la negació dels verbs modals i auxiliars en l'anglès Black Country a través de fonts històriques $\mathrm{i}$ actuals que informen d'aquesta introducció. Tot seguit, s'esbossen les regles fonològiques que han regit les dues principals estratègies en competència, una de les quals continua dominant el sistema de negació localitzat actual. Seguidament s'examina l'aparició d'una nova estratègia sobre una altra i s'analitza el període de temps en què aquest fet podria haver passat, utilitzant tant enquestes de dialectes com fonts literàries. Finalment, s'examina l'estratificació sociolingüística de les formes negatives locals i el significat

\footnotetext{
${ }^{*}$ School of Humanities, Housman Building, Camp Street, Wolverhampton, WV1 1AD.
} 
sociolingüístic que té dins de la comunitat de parla moderna. Per a aquesta darrera secció, s'utilitza un corpus modern obtingut de 39 residents de Black Country, que es va recopilar entre el 2003 i el 2006.

Paraules clau: negació verbal, mutació ablaut, Midlands English, contacte dialectal, lingüística històrica

ESTRATEGIAS DE NEGACIÓN VERBAL EN EL “BLACK COUNTRY” - VARIACIÓN ESPACIAL Y TEMPORAL Resumen

Este artículo examina datos de la variedad de lengua tradicional del área Black Country de West Midlands de Inglaterra; un área que se encuentra directamente al oeste de la ciudad de Birmingham. Se presentan las estrategias que se han utilizado a lo largo del tiempo para marcar la negación de los verbos modales y auxiliares en el inglés Black Country a través de fuentes históricas y actuales que informan de esta introducción. A continuación, se esbozan las reglas fonológicas que han regido las dos principales estrategias en competencia, una de las cuales continúa dominando el sistema de negación localizado actual. Seguidamente se examina la aparición de una nueva estrategia sobre otra y se analiza el período de tiempo en que esto podría haber ocurrido, utilizando tanto encuestas de dialectos como fuentes literarias. Finalmente se examina la estratificación sociolingüística de las formas negativas locales y su significado sociolingüístico dentro de la comunidad de habla moderna. Para esta última sección, se utiliza un corpus moderno obtenido de 39 residentes de Black Country, que se recopiló entre 2003 y 2006.

Palabras clave: negación verbal, mutación ablaut, Midlands English, contacto dialectal, lingüística histórica

\section{An introduction to the Black Country area}

The Black Country lies in the western Midlands of England; its eastern border is formed by the city of Birmingham. It is located at the southern end of Staffordshire and the north of Worcestershire. The name Black Country is of obscure origin, but generally acknowledged to have semantic links with the heavy industry in the area, which arose with the birth of the Industrial Revolution. The major issue faced by all those who wish to research the area, and by implication, the language varieties within it, is that the Black Country exists only in abstract terms. It has no geographical boundaries, nor any founded historically on political or administrative divisions. Asprey (2007) takes a deliberately wide view of the area, circling all areas which historians consider to have a high concentration of coal mines and associated ironworks and steelworks (they ultimately causing the air pollution which made the blackness in Black Country). Figure 1 below shows a map of the area in UK context, and Figure 2 delimits an area within which the speech community discussed I this paper resides. 


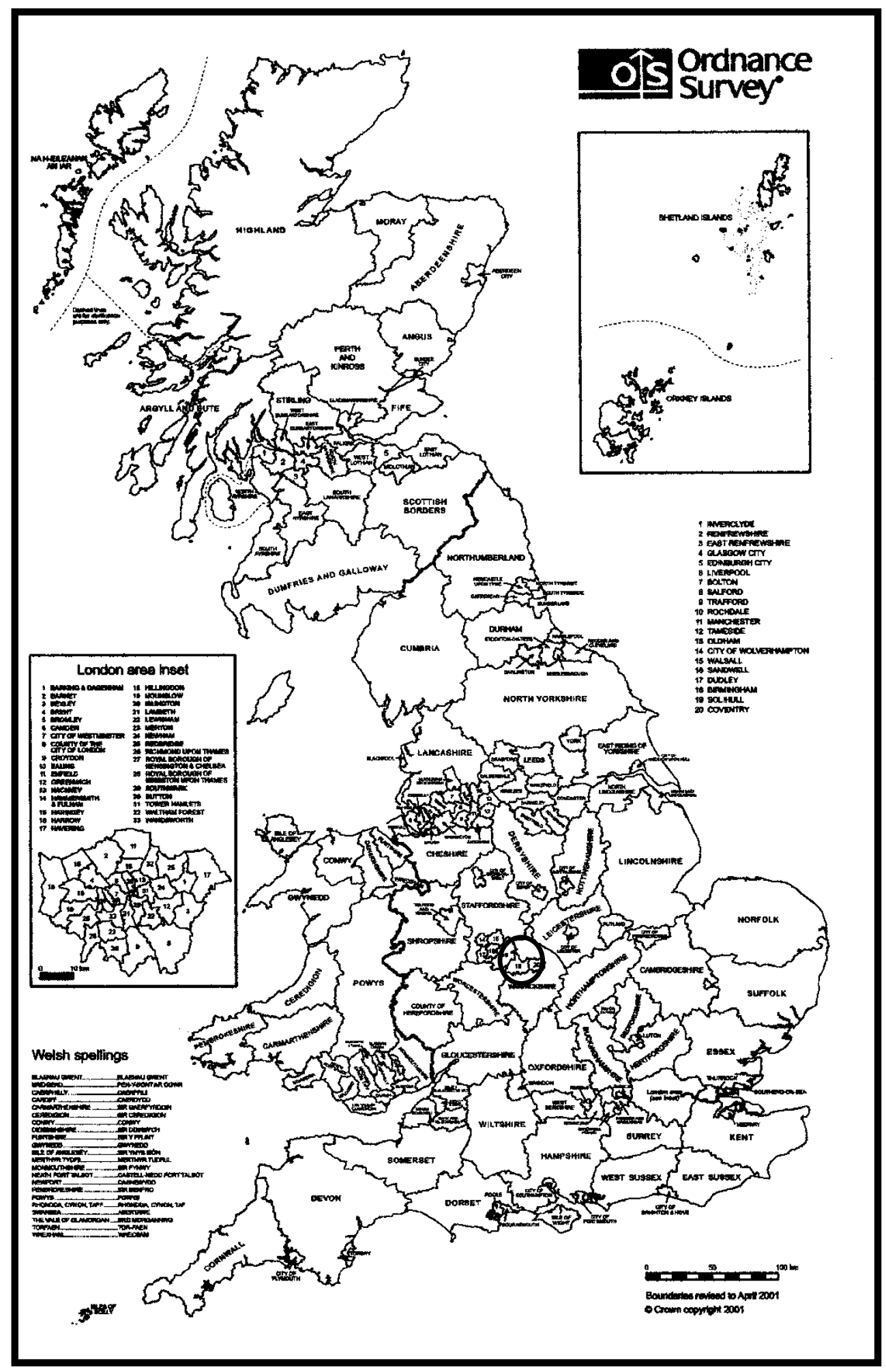

Figure 1. Location of the Black Country within the UK (Map outline reproduced by kind permission of the Ordnance Survey). 


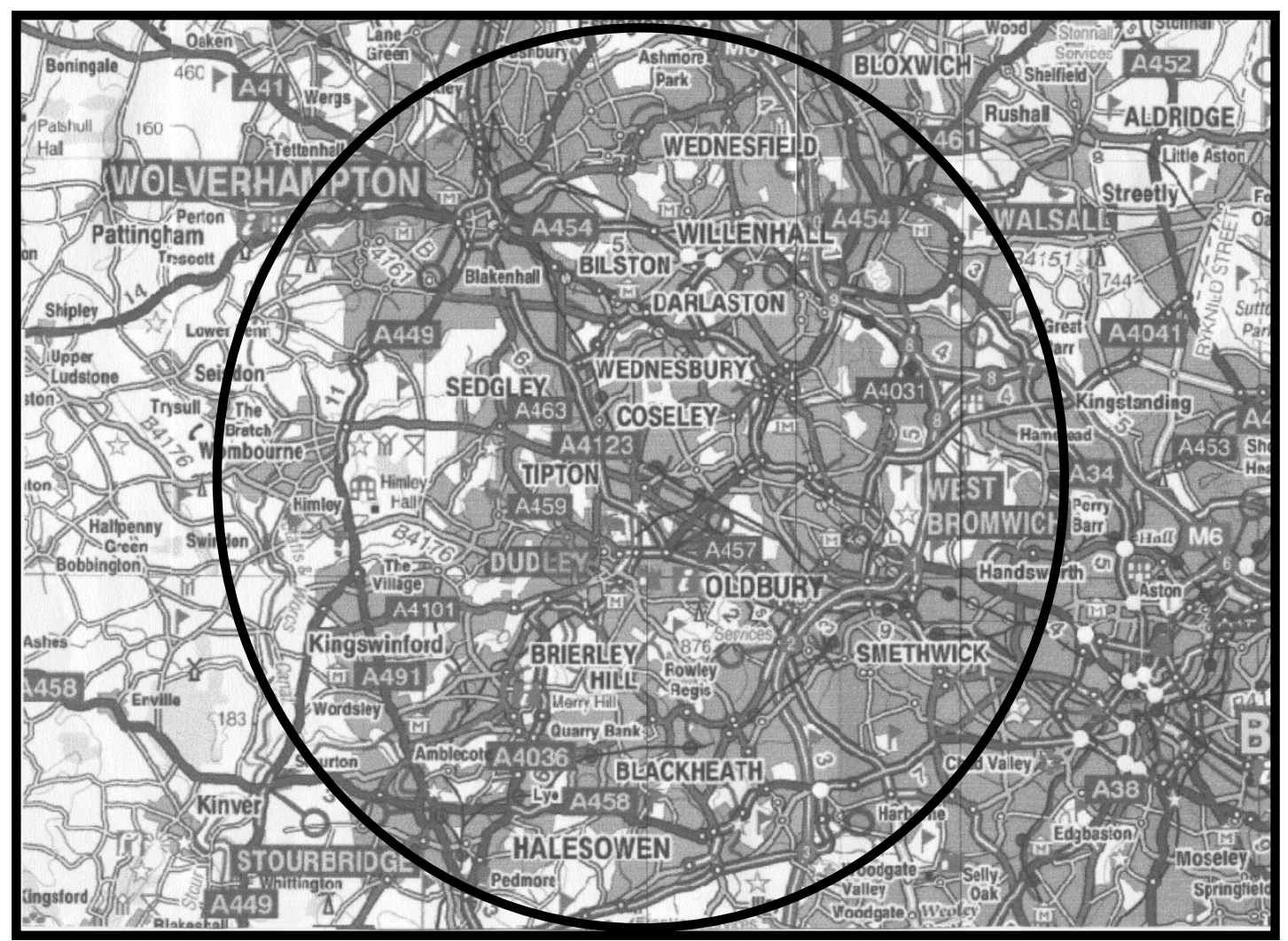

Figure 2. Approximate location of the Black Country (Map reproduced by kind permission of the Ordnance Survey).

\section{Verbal negation strategies in English: a theoretical overview}

Anderwald (2002: 20-21) discusses the negation of verbs in detail. She describes how standard English negation moved from use of a preverbal particle ne in Old English to two particles in Middle English, the post verbal deriving from the lexeme noht (no one, nothing):

1. Ic ne secge $\rightarrow$ I ne seye not

She then discusses the rise of periphrastic do which leads to PDE

2. I don't say 
Before discussing the exceptions to the rule - lexical verbs BE and HAVE, as well as the central modal verbs. These verbs can negate without periphrastic DO support. They will form the basis of my examination in this paper. Anderwald (2002: 25) discusses contraction strategies for these verbs:

Contraction of the negator not to $n^{\prime} t$ is a relatively recent phenomenon; its beginnings are usually dated at around the middle of the seventeenth century. It parallels the development in stage 1 of Jespersen's cycle (1917: 4) supporting Jespersen's assumption that the (originally strong) negative marker is weakened phonologically through time (This might of course lead to further additional strengthening, putting Jespersen's cycle into swing again).

She continues (2005: 64-65):

Traditional dialect speakers, especially in the northwest Midlands area, have a negative clitic in - no as shown in much detail from the SED maps (Orton, Sanderson and Widdowson 1978) [...] a core area can be determined touching Cheshire, Derbyshire., Shropshire and Staffordshire, in addition to the border area with Scotland [...] Britton (1992) also documents an /nə/ clitic for the Northwest Midlands [...] Moving to a different morphological phenomenon, based on SED material, Britton (1992) records secondary contracted forms of negative contracted verbs to $/ \mathrm{t} /$ rather than the much more usual $/ \mathrm{n} /$." $^{\prime}[\mathrm{i}] \mathrm{n}$ the Black Country in southwest Staffordshire, west of Birmingham, the negative clitic /nt/ is not only reduced to $/ t /$ but deleted altogether.

Anderwald sets out the rules for the status of the negative verb forms as separate morphemes in the Black Country:

This contraction, originally determined by purely phonetic criteria, has resulted in a negative system that is very unusual typologically, maybe even unique [...] Because of the highly marked status of these verb forms, it is therefore not surprising that in southwest Staffordshire only a subset of negative contracted verbs can be further contracted in this way (2005:67). I describe now the data I have which show the coexistence of negative forms in the Black Country and the rise of the secondary contracted form over time. 


\section{Verbal negation strategies in the Black Country across time}

There are broadly three systems in operation across time in the Black Country region. There is a standard system with some kind of negative clitic $\langle$ not $\rangle$ or $\left\langle n^{\prime} t\right\rangle$, a Midlands system ending in [nə] and a system relying on ablaut mutation to mark a negative verb for modals and support verbs. In his comprehensive dialect survey of 1889, Ellis (1889: 463) remarks that his transcription system "gives a good conception of the Black Country speech. The peculiar form of the negative is well brought out". Across time it can be seen that one major negation strategy for modal and auxiliary verbs in the Black Country speech variety has been the use of ablaut (vowel mutation) rather than a negative suffix as in Standard English. Ellis's remark that this form is peculiar to the region is true in the sense that such a form appears to exist only in the Black Country and its immediate environs.

The ablaut system has, as far as historical spoken and written evidence can tell us, only ever been used with auxiliary and main verbs HAVE and BE, together with modals, SHALL CAN, MUST, WILL, DO. It can be dated in writing to as far back as 1817, when it is clearly seen in this parody exchange discussing voting for a Worcestershire MP by Martin Danvers Heaviside (1817):

3. Dudley Man. "Oi say, surree, hew dust thee vowt for?"

Stourbridge Man. "I caw tell - I've not made up my moind."

Dudley Man.- "Whoysna vowt for ---? Thur best feller ee the wurrld; damned his own feyther at foiv' 'ear ode"!

The modal verb CAN has been negated to [kJ:]. This strategy is still in use today and can clearly be seen in data gathered by Asprey (2007), where it is noticed and discussed by informants. $92 \%$ of Asprey's informants reported hearing the construction, with $36 \%$ reporting that they used it. Of those who used it, $42 \%$ were under 40 . What does seem likely is that younger speakers are bringing the form closer to the standard [ka:nt] by using [ka:], which derives from the standard [ka:n] rather than Black Country local variety [kpn], so one finds for example: 
4. "erm, I [ka:] think of any others"

This said, the strategy of ablaut negation does not appear in common use throughout the region for quite some time. On the contrary, the dominant strategy historically is linked to the more common strategy of adding a negative particle to the verb. This manifests as [nə] for most verbs. This strategy is found in Orton and Barry's Survey of English Dialects in the counties of Cheshire, Derbyshire, Herefordshire, Shropshire, Staffordshire and Worcestershire. In addition to this, speakers also have recourse to the standard negative particle [nt] for verbal negation.

I now examine the earliest dialectological evidence for the Black Country by looking at Ellis (1889: 464-465), who collected oral data from locations across South Staffordshire and North Worcestershire, and found the forms we see tabulated in Table 1 in the Appendix. In essence, the small amount of evidence from Ellis suggests that the standardised forms may be coming from the south and east and that Cannock and Dudley have some vestiges of the older system (the one count of [don] in Dudley is possibly a contraction of [donə] but might equally derive from [dənt]).

It is notable though that even in Mid Staffordshire the more standard forms are also appearing. Ellis himself has seen fit to write a footnote concerning ablaut negation which runs thus:

I don't care, that don't matter, ...the peculiar method of expressing the negative in conjunction with auxiliary verbs. I have not met with it elsewhere, but Mr Elsworthy says he was met with it in Sm. [Somerset]; it is, however, as far as I know, unrecorded (1889: 1902).

Ellis also highlights the same usage in Darlaston, some 6 miles north of Dudley. There he noted especially some sentences with ablaut negation:

5. "I [kJ:t] do it, and I [ert] a-going to do it, nor I [jeət] because I [du:t] know what it is.

6. He's out of work and he [kJ:] get none. 
Of special interest here is the link between the form with a $[t]$ ending and the emergence of a form completely reliant on ablaut.

I turn now to the evidence collected almost fifty years later in the region for the Survey of English Dialects. Orton and Barry's fieldworker for Staffordshire, Peter Gibson, is still recording evidence for the [-nə] form in the Survey of English Dialects at location 11:12 (Himley). The question posed to elicit negative particles in the SED with its cloze test like formula is:

... [Y]ou might say: Get away, I ... drunk

and the response given ends up with many informants ignoring the framing and giving a dialect form of the verb which does not use the standard negative particle:

[aI عI] or [aI Inə] "older" [remark made by the informant in explanation] (Orton \& Barry 1971: 1054).

The other question posed was a direct request for informants to give their forms of

I'm not

She isn't

They aren't

Results can be seen in Table 2 shown in the Appendix. We see that the SED uncovers both forms of the negative and that the [-nə] form is considered by one of the two informants in Himley as older. Comparing the forms with the locations closest to Himley, however, reveals that in locations closest to Himley (Romsley in Worcs, Hockley Heath in Warks), the [nə] form still exists and is also competing with a more standard form and an ablaut form for some verbs. The main issue with such a data set is that although informants were meant to be non-mobile, this was not always the case. The informant recorded at location 11 in Staffordshire was in fact highly mobile compared to many - a market gardener who travelled 10 miles every week to 
Kidderminster from Himley to sell vegetables. Added to this is the issue of low frequency (tokens being elicited and appearing relatively infrequently in spoken conversation) and that of salience (Kerswill \& Williams 2011). It is clear that SED data can give us only an indication of forms speakers know and is less useful as a guide to what they actively use.

More substantial support is found in the lyrics of songs and in dialect poetry. Bartlett (1886), writing in Bilston, gives many examples:

7. S'pose yoh wunna mind a sittin'

Down a bit on this 'ere bench?...

Bob's bin sent back from the schule,

And 'ee conna walk - 'ee's lyin'

On the path be th'owd pit pule...

Un the kids, nor me, nor missus,

'ad'na gorra a grub ter eat.

The only auxiliary, modal or do support verb he gives which is not formed using this strategy is the verb do, which is negated as 'doh' [dov]. Raven \& Raven (1966) give the lyrics for 'The Battle of Bilston', a poem without an attested author concerning a cockfight, published in the Bilston Almanac in 1923:

8. For he pecked like a miner a-holin',

And struck clean and straight with his spurs,

"By Christ" says 'Old Bull's Head' "he's a true 'un"

And let him say he binna, wot dares.

It shows the use of these forms, but also goes on to give the past tense using the [ənt] form '[b]ut the Bils'on cock warn't yet beaten'.

It is Raven \& Raven (1965: 59-60) who also reproduce the humorous anonymous $19^{\text {th }}$ century poem 'Christening the wench Ben', set in the Lye (1 mile NE of Stourbridge). In one verse there is both 'dain't you spake?' and 'dunna be taking so silly'. Indeed, examining local variety evidence thoroughly leads to an initial hypothesis 
that it may have been operator do which was the first verb to conform to the newer negation strategies of first -nt marking, and later, vowel mutation. Have and be appear to remain negated using the -[-nə] strategy for longer, as do the modal verbs.

Evidence from dialect poetry suggests that different strategies of negative verb marking have been in competition over the past two centuries (and maybe earlier; any evidence of this is still to be found). A more standard strategy [nt], a Midlands strategy of [nə], and an emergent strategy employing ablaut rather than suffixation have all existed. Freeman (1931: 4) is of the opinion that

A hundred years ago two forms of dialect were in common use in the Black Country. Naturally they were closely akin and had many terms in common, but the accent with which they were spoken was noticeably different; the one native to the immediate district was direct and emphatic, while the other, brought by the mining families from the neighbouring County of Shropshire was softer and intoned with a musical lilt.

This popular idea was articulated by many of those interviewed in Asprey (2007) as well, though some replaced the influence of the intonation of Shropshire with that of Welsh incomers. On the basis of his theory, Freeman concludes that a gulf between 'native dialect' and 'Shropshire dialect' was the reason for the /nə/ forms which appeared as opposed to 'native' forms such as I who, I cor, I doh (his respelling). I suggest instead that the oldest strategy /nə/, though possibly reinforced by incomers from Shropshire, was the original native form. I hypothesise that a standard strategy of [nt] came in to the area, allowing forms like 'dain't' [deint], 'ain't' [eint], 'int' [Int], and that these forms were reduced, their vowels nasalised, and eventually, that the suffix was lost to produce total reliance on vowel mutation to mark time difference. Intermediate morphological forms also exist, and the semantic changes they have undergone can be documented using historical evidence. Manley (1971: 57) reports that the 'addition' of [t] to negative verb forms marks emphasis:

When the negative forms /dei, ei, bei, $\int \mathrm{J}_{\text {: }}$ wo:, $\varepsilon:$, ko: / occur finally in the sentence, ' $t$ ' is added to them; this usually, though not always, indicates some degree of emphasis on the part of the speakers (contempt, disgust, etc.): 


\section{e.g. /distlark3:/? /pdert/! /kpstdiuctnau/? /pko:t/!}

Britton (1992: 48) does not believe that the Black Country forms derive from [-nə] forms:

Could it be that all the enclitic-deleted forms are actually derived from /nə/ negatives and not from /nt/ forms at all? The answer [...] is an appropriately negative one: the evidence for diachronic and synchronic variation between forms with $/ \mathrm{t} /$ and $\varnothing$ argues powerfully against derivation of the $\varnothing$ forms from /nə/ forms, as also does the difficulty of deriving [de:] from [didnt] [...] [dov] transparentlyderives from [dov(n)t] rather than [donə]; and [...] [e:] cannot descend from [anə] or [Inə] but must have its ultimate origin in [e:nt].

There is evidence that the [nə] forms still exist in the receptive knowledge of older speakers, whether or not they are ever used. Walker (undated) in his 1980s dictionary of Black Country based on his local Wednesbury version of the variety gives

conna - cannot (undated: 15 )

dunna - don't (undated: 17)

wunna - will not (undated: 39)

Conduit (personal communication) remarks that his Darlaston informant, 63 at the time of interview in 2004, gave the forms [donə] and [Janə] at interview. Conduit remarks that this appears to be the largely obsolete Staffordshire method of negation. Conduit's informant remembered this from the speech of his maternal grandmother, who was born in Darlaston. One of my own elderly informants recorded in 2006 also remembered this as present in the speech of his maternal grandmother, who was born in Darlaston.

Some more nuanced data are discussed by Freeman, whose literary sketches are set in the town of Bilston. Like most Black Country towns, Bilston had many collieries and iron works and saw immigration from Shropshire, and Freeman's excerpts are interesting. 
Freeman's data consists of tales from Bilston. Bilston is well known for incomers from Shropshire come to mine coal, yet in Freeman's sketches, nearly all the characters use the [nə] form of negation, despite his insistence that this is a typically Shropshire form of negation. If it is, then it has certainly spread amongst the nativeborn Staffordshire population, since in his tales there is constant mention of [nə] negation. The following excerpt makes this quite clear:

"Ikey's a-dooin well, I'm obleeged to year". Jokey's look of impatience was followed by a rogueish laugh, then he replied: "Dooin well, thee said'st!- it's loike mintin' money at them pits".

"An he'll saave it, yo' knowin'. T'other's spendin' golden sovereigns by hon'fuls at the "Hond an' Kays", but yo' dunna see lkey theer, not but what he loikes his mug o'beer said Tomty.

A knowing smirk from Jokey was followed by:

"But it's a toss up betwixt the brass an' the beer, an' every fule knows the brass'll allus win wi' Ikey. He goes to the Greyhound for his drap, where O'd Straight Face wunna fill moor nor two glasses for onny mon".

"He's reg'lar enough at 'Top Chapel' they tellin' me - but I'm feared he dunna do the Place no good" trembled out the piping voice of old Tomty.

"He's theer for what he con get, thee cost put that down for sure" snorted Jokey.

"But they'm on'y hard-workin' men, they han nothin' to gie him". With a contempt that came easily to Jokey he sniffed at old Tomty, and said: "Thy yed's thicker nor I thought dusna see he goes to pray for good luck at the pits?"

(Freeman 1931: 5).

Some characters in his work do use negation, which is close to ablaut. The following account of a practical joke to steal the barber's pole shows this clearly:

"How is it thee'st got ne'er a pole o'er the door, Jack?"

"I've got a pole for sure, thee gawby" answered Jack.

"Has he lads?" the joker asked, appealing to others who were in the conspiracy. To the barber's astonishment they answered:

"No, he's got no pole, he cort afford no pole".

(Freeman 1931: 12)

Similarly, the tale of a young family from Sedgley seeking a minister to christen their baby contains more standard like negation (Raven \& Raven 1965: 8): 
now you goo, and say we'n come a' purpose, and some'at bad's ommust sure to happen if he don't come.

The minister does christen the child, but mistaking the couple's surname of William for a first name, gives the little girl a boy's name, resulting in an altercation:

When the Vicar came, he enquired: "well, what have you done?"

"It ain't what we'n done, it's what you'n done, Mr Lewis".

Freeman's sketches of the northern Black Country then, provide mixed evidence for the existence of different negative forms.

By 1971 when operator DO is discussed by Manley (1971: 44-45), she finds the older forms which show both the influence of the dual second person subject pronoun system, which was in common use in older Cradley Heath speakers at the time she interviewed them. The majority of her informants were older men who had worked making chain in Cradley Heath for most of their lives, with the notable exception of World War Two. Table 3 shows the loss of the negative copula in both the present and past negative paradigm (with the exception of second person singular, as discussed).

\begin{tabular}{|c|c|c|}
\hline Present tense negative & Past tense negative & Future time reference negative \\
\hline D dor & D deI & $\mathrm{p} \int \mathrm{D}: \mathrm{d}$ Iə, $\mathrm{D}$ or diə \\
\hline ঠi: d^snt & đi: disnt & \\
\hline i: 3 : It dor & i: $3:$ it deI & \\
\hline wi: dor & wi: deI & \\
\hline jor dor & jor deI & \\
\hline ðer dor & ðeI deI & \\
\hline
\end{tabular}

Table 1. Negative paradigm - to do (Manley 1971)

Since the decline of 'thee' and 'thou', the Black Country forms of doNEGPAST and dONEGPRESENT are levelled at [dei] and [dor] respectively throughout the paradigms. 
This also applies to the use of do as a main verb, though there is a continuum of more - less Black Country with some 'compromise' possibilities lying between the Black Country and the West Midlands standard forms. The interesting correlation is between the older pronoun and the more standard form of negation. There is no documented instance in the admittedly limited range of data I present which suggests that thee can co-occur with a form using ablaut negation. This would support the evidence that ablaut negation is a newer strategy.

3.1 Use of the ablaut negative in the present day speech community - some conclusions

At this stage in the discussion of do as operator verb it is appropriate to discuss some data which looks at the forms of both main verb do and operator do in the past tense. The data in Asprey 2007 focus on the variants of the past negative verb form of the verb do. One important methodological decision concerning the investigation of this variable was that of collating operator do with main verb do. Preliminary examination of the data revealed that the same variant forms could appear regardless of whether do was the operator or the main verb in an utterance. It seems clear that future research could be designed to investigate the incidence of one variant over another dependent on grammatical function; however, the purpose of my analysis was to examine use of variants over time and according to social class, rather than to grammatical function.

The variants of dOPASTNEG which can appear are as follows: there is first the ablaut form which was discussed in the previous section, which runs [der] throughout the paradigm. There exist then a range of what I term intermediate forms (though I do not use this term 'fudge' since this might imply that speakers are attempting to approximate to the standard forms; to do so would be presumptuous at this stage in my examination). The intermediate forms, then, range from [deInt], a clear mixture of the ablaut vowel but with a negative particle added, through to [dint], a form which elides only the $[d]$ of the contracted standard form [dIdnt]. Another intermediary (which preliminary analysis suggests is more commonly found among women) is 
[di:nt]. It is harder to see where this form fits into any continuum - it has a negative particle attached, suggesting a more standard-like realisation, but conversely, the vowel is a lengthed one, possibly suggesting something closer to the local ablaut form. Finally there are the standard forms [dIdnt] and [dIdnot].

Informants had been asked about the ablaut form at interview. Their sheet 'more about language' had contained 3 test sentences: 'There was a crash on the M6 last night, but I day see nothing', 'It day seem fair, giving them all that money' and 'We day buy it'. It was clear from the data gathered about this that the form is widely known among speakers. Collating results from the test sentences shows that $97.4 \%$ of speakers had heard the form in their area, but only 23.15 reported using it. Of the speakers who reported using the form themselves, $66.7 \%$ self-declared working class origin, $55.6 \%$ were male, and only the $61-70$ age group did not contain any speakers who reported using the form. The most likely age groups to contain speakers reporting use of the form were the 27-40 and 41-60 groups: in each test sentence 3 speakers from each of these groups reported using the form.

Qualitative discussion among speakers concerning this variable is well exemplified in the following exchanges from Asprey (2007):

9. EA "Would either of you use 'ay' and 'day' and 'cor'?" INF A "No"

INF B"Erm(.)maybe when I was at school I would have used those more but I don't(.)| tend not to say them now(.)it's more(.)It's quite conscious that you don't say them I suppose"

INF C "I would never say like 'ay' or 'day' I would never say that(.)that is something that" EA "do you hear these things?"

INF C "Oh all the time(.)that's how everyone speaks(.)everyone around me"

10. EA “so 'ay'(.)you wouldn't use 'ay'(.)does that grate on you [EMPHATIC] as well?" INF D "it doesn't really grate on me(.)but a lot of people use it" INF E "ay' doesn't(.)'day' does [LAUGHS](.)'day' is the worst" INF D “yeah I don't like 'day' (.) I don't mind 'ay'(.)but

\section{a. INF 2 "a lot of people say 'ay"”}

EA "A lot of people say 'ay' (.) and it's also not so far from ain' $t$ " INF F "yeah I do say ain't" 
It is clear that for these four informants at least, [der] is stigmatised, and they seem more likely to be accepting of local forms for haveNEGPRESENT and beNEGPRESENT. This tallies with evidence presented above which shows a marked difference between use and knowledge of [der].

Asprey's 2007 results show that $25.6 \%$ of her informants actually use the local variant [der] at interview. The figure tallies well with the self-reports the informants gave; usage is very slightly underreported, but a $2.45 \%$ level of difference (in favour of underreporting) displays remarkable accuracy on the part of those doing the selfreporting. Of those who reported that they would not use the form, only two informants actually did so at interview. Both informants were male, and neither displayed animosity toward the variant at interview. The first used high levels of many local grammatical forms, especially the local forms of beNEGPRESENT, haveNEGPRESENT and benEGPAST. He also used the local system of determiners, and his phonology was very localised. INF 30, by contrast, did not feel that he spoke a variety which was heavily localised. He talked of having changed the way he spoke when he started work, and it was indeed the case that he did not use many local grammatical forms. His use of the local variant only occurred once (his other two occurrences of the variable were the standard variant).

A breakdown of usage by gender shows three female informants who use the local variant compared to seven men. There is no age group which does not contain a speaker who uses the local variant, though the age groups containing the least number of informants using the local form are the 27-40 and 61-70 age groups, even though one of the groups most likely to contain speakers reporting that they used the form was the 27-40 group. There are three informants who reported that they would use the form and do not in fact do so at interview. INF G discussed his ideas of situational styleshifting and motivations for it quite openly at interview, and his comments relate directly to his choosing a fudge form of haveNEGPRESENT during the interview:

b. EA "To what extent would you say that you use Black Country grammar(.)you know to what extent do you say 'I [ei]' and 'I [bei]' and 'I [dei]' and 'I [ko:]' (.)does it depend who you're with?" 
INF G "Erm it does a little bit yeah because I have to speak to people from other areas of the country on the phone where I work and that so I but(.)I do use them and things drop in occasionally like you know I might be [UNCLEAR] somebody and I'd use the word [mi] instead of [mai](.)I [ei] done [mi] speech [for brother's wedding - EA] yet"

EA "And you would say [ei]?"

INF G "Yeah(.)or I'd say [eint](.)you've got both(.)yeah(.)I [eint] done [mi] speech yet(.)I'd probably say ain't if I was a little bit unsure(.)it's not I don't even think about it(.)do you know what I mean(.)if I was speaking to you I would be more inclined to say I [eint] done [mi] speech yet than say I [ei] done it"

EA "Why?"

INF G “Because(.)I don't I don't know because I don't know you so well(.)and knowing that you're from Walsall(.)l don't really know Esther(.)she's from Walsall(.)she's not necessarily going to understand(.)I'll make myself sound a bit common if I say [ei] and that"

INF G was a speaker Asprey observed in conversation before as a friend of a friend, and he did, as he reported, use local forms in situations less formal than the interview. However, he used a mixture of the standard, fudge and local forms of beNEGPRES and haveNEGPRES during his interview, and the standard form of doNEGPAST throughout his interview. He did not restrict himself to only using fudge forms of haveNEGPRES as his comments above might suggest; indeed, he had already used the local variant [ei] at interview before the exchange given above had taken place. This discrepancy in his own report makes it doubtful to suggest that he might never use either the local or the fudge variants of doNEGPAST.

In contrast, INF H and INF I only use the standard variant. INF H has five instances of this. There seems no clear motivation for her having reported that she would use the form. She also appears to have overreported on her interview from her use of the local variant of haveNEGPRES, since at interview she only ever used the standard variant. As an informant she was very enthusiastic, finding many alternatives for each notion word, and was quick to come to the defence of the Black Country area and the language associated with it. Her Identity Questionnaire showed that she identified positively with the area. It may be that such speakers overreport using variants. Conversely, it may be the case that this speaker chose the use of the standard as her strategy for avoiding the local when interviewed. More research is needed in the Black 
Country on situational motivation for choosing different variants at different times. Higgs (date) has examined grammatical variation in the third person singular female object pronoun and found that the local form /3:/ is used more when speakers claim solidarity and a common identity with their interlocutor. I made no claims to be a Black Country speaker or resident in conducting my fieldwork, and this may well have influenced the responses I got.

All 5 informants in Asprey (2007) who used some kind of intermediate variant for dONEGPAST are over the age of 50 . None used this intermediate as their only variant of doNEGPAST. Of the five, two also used the standard form, and three also used the local form. None employed all three strategies. Self-declared class for four out of the five speakers was working class; only one declared middle class. It is difficult to see clear lines along which this data can be interpreted since there is not enough data to draw convincing conclusions. Further investigation should focus on the phonological context of each variant, and on devising a methodology which might be more successful at gathering more instances of the variable, which occurs remarkably infrequently in unstructured conversation.

The negative form of have in the second person singular has regularised over the 30 years between Manley's data collection and Asprey's. Table 4 shows this clearly.

\begin{tabular}{|c|c|}
\hline Present tense negative (older) & Present tense negative (newer) \\
\hline DI æn $\rightarrow$ eI & DI æv $\rightarrow$ eI \\
\hline di: æst - æsnt & jou æv $\rightarrow$ eI \\
\hline i: 3: It æz $\rightarrow$ eI & i: 3: It æz $\rightarrow$ eI \\
\hline wi: æn $\rightarrow$ eI & wi: æv $\rightarrow$ eI \\
\hline jov æn $\rightarrow$ eI & jou æv $\rightarrow$ eI \\
\hline deI æn $\rightarrow$ eI & deI æv $\rightarrow$ eI \\
\hline
\end{tabular}

Table 2. Auxiliary verb to have - negative forms (Manley 1971/Asprey 2007) 


\subsection{Auxiliary 'be' - affirmative and negative}

Even in Asprey 2007, however, there remain two competing forms of the main verb and auxiliary verb be. The normal paradigm in the present tense among speakers closer to the Black Country end of the speech continuum is as follows: Two forms of the verb be are given in Table 3, the positive/negative 'bin' / 'bay' combination is the older form, but both the 'bin' / 'bay' and the 'am' / 'ay' combinations are currently in use in the Black Country. Evidence from my data shows this to be so, and Table 4 clarifies it. The forms beginning [b] are, as has been mentioned, dropping rapidly from the speech of all but the most elderly users. The norm at the Black Country end of the continuum is now syncretism with the negative past paradigm of have. In the past form there are also competing variants within the region. In the past, levelling of the verb appears to have taken place in the direction of 'were' forms (as in much of the northern Midlands and the wider north).

\begin{tabular}{|c|c|}
\hline Present tense negative (older) & Present tense negative (newer) \\
\hline DI beI & DI eI \\
\hline di: bisnt & jov eI \\
\hline i: 3: It æz beI & i: 3 : I eI \\
\hline wi: beI & wi: eI \\
\hline jov bei & jov eI \\
\hline ðег beI & ðег еI \\
\hline
\end{tabular}

Table 3. Auxiliary verb to be - negative forms (Asprey 2007)

We can say then that informants vary negation strategies even within a sentence; there is a continuum for them of more and less standard. For present tense be and have, such variation is particularly noticeable.

INF K produces [ti:nveriofn] where careful standard speech might have [ItIsnt]. It is clear though, that this is a grammatical construction not found in the standard - the fronting of the verb phrase where the standard would be more likely to have the subject pronoun beginning the clause. Her sentence had been '[ti:nveripfn] you hear that anymore'. This may mean that Black Country local variety speakers have more 
opportunities to use a reduced form of the verb be. INF $L$ within the same recording dyad mirrors the construction by answering his wife [novIrIsntnæo]. INF K repeated the utterance given at 3.39 seconds but this time realises the verb as [tæ⿸ ${ }_{1}^{2}$. Such reduction lends weight to Britton's theory that some negating strategies are the result of reduced [nt] forms.

\subsection{Modal verbs - affirmative and negative}

Certain modal verbs still use the strategy of ablaut. Table 4 (from Manley 1971: 41-46) gives the paradigms for the verbs can, shall and will in the second person singular affirmative and negative forms.

\begin{tabular}{|l|l|l|}
\hline jou kan $\sim \mathrm{knn}$ & $\mathrm{a} \sim \mathrm{p} \rightarrow$ : & jou $\mathrm{kJ:}$ \\
\hline jou fal & $\mathrm{a} \rightarrow \varepsilon:$ & jov $\int \varepsilon:$ \\
\hline jou wIl & $\mathrm{I} \rightarrow$ ov & jou wov \\
\hline
\end{tabular}

Table 4. Affirmative and negative verb forms (after Manley 1971)

Of those given, will and can still have relatively high levels of use among all ages at the Black Country end of the speech continuum. I asked informants about canNEGPRESENT in my questionnaire, and found that $92 \%$ hear the construction, with $36 \%$ reporting that they used it. Of those who used it, $42 \%$ were under 40 . What does seem likely is that younger speakers are bringing the form closer to the standard [ka:nt] by using [ka:], which derives from the standard [kan] rather than Black Country local variety [kon], so one finds for example: INF I "erm, I [ka:] think of any others".

\section{Conclusions and directions for future research}

Ablaut negation in the Black Country arose some 250 years ago from more standard negated forms using /nt/ clitics. Alongside them I have presented evidence 
from literature and spoken dialect that the /nə/ forms were also in use across Staffordshire and Worcestershire, and that despite folk linguistic theories that these were a Shropshire import (they may indeed have come to represent Shropshire incomers) the likelihood is that they are the older Staffordshire form in the region. The ablaut strategy is lost in the verb SHALL now but persists even among younger speakers and despite some social condemnation of the phenomenon in all other central modal verbs and the high frequency verbs DO, BE, HAVE. This use of a marked form is unusual and a more detailed look at how it patterned socially and patterns socially today is the next step needed.

\section{References}

ANDERWALD, Lieselotte (2002) Negation in Non-Standard British English: Gaps, regularizations and asymmetries, London: Routledge.

ASPREY, Esther (2007) Black Country English and Black Country Identity, Unpublished PhD thesis, Leeds: University of Leeds.

BARTLETT, F. (1886) "The Collier's Story - A tale of hard times", in F. Bartlett, Flashes from Forge and Foundry, Bilston: Shakespeare Printing Co., 27.

BRITTON, Derek (1992) "Secondary contraction and deletion of negative enclitics in English dialects", Zeitschrift für Dialektologie und Linguistik, 59, 38-49.

HEAVISIDE, Martin Danvers (1817) "Dialogue between a Dudley Man and a Stourbridge Man", The Morning Herald. Rpt. in Davenport-Hill, Rosamond and Davenport-Hill, Florence. 1878. The Recorder of Birmingham. A Memoir of Matthew Davenport-Hill. With Selections from his Correspondence, London: MacMillan.

ELLIS, Alexander (1889) On Early English Pronunciation, with especial reference to Shakspere and Chaucer. Part $V$, London: Trübner and Co.

Freeman, John (1931) Black Country Stories and Sketches, illustrating life in the Staffordshire Black Country, Bilston: James Wilkes.

JESPERSEN, Otto (1917) Negation in English and other languages, Copenhagen: Det Kgl. Danske Videnskabernes Selskab. Historisk-filologiske Meddelelser. 
KeRSWILL, Paul \& Ann WILLIAMS (2011) "Salience as an explanatory factor in language change: evidence from dialect levelling in urban England", in Mari Jones \& Edith Esch (eds.), Language Change: The Interplay of Internal, External and Extra-Linguistic Factors (Contributions to the Sociology of Language, Berlin: Mouton De Gruyter, 81-110.

MANLEY, Sandra (1971) The Black Country dialect in the Cradley Heath area, Unpublished M.A. dissertation, Leeds: University of Leeds.

ORTON, Harold \& Michael BARRY (eds.) (1971) Survey of English Dialects (B): The Basic Material Volume 2 - Part 3 - The West Midland Counties. Leeds: E.J. Arnold.

ORTON, Harold, Stewart SANDERSON \& Charles WIDDOWSON (1978) The Linguistic Atlas of England, London: Croom Helm.

RAVEN, Michael \& Jon RAVEN (eds.) (1965) Folk-Lore and Songs of the Black Country and West Midlands - Vol. 1, Wolverhampton: Wolverhampton Folk Song Club.

RAVEN, Michael \& Jon RAVEN (eds.) (1966) Folk-Lore and Songs of the Black Country and West Midlands - Vol. 2, Wolverhampton: Wolverhampton Folk Song Club.

WALKER, Edward (undated) The definitive Black Country dictionary, Wednesbury: E. Walker. 
Dialectologia 28 (2022), 57-80.

ISSN: 2013-2247

Appendix 1

Raw tokens of negation from Ellis (1889) - locations closest to the Black Country

\begin{tabular}{|c|c|}
\hline Location & Negation strategy \\
\hline Dudley, Worcestershire & $\begin{array}{l}\text { BEneg [eint] } \\
\text { Doneg [dov] x 4, [dvn] } \\
\text { BEneg [eint] } \\
\text { WILLneg [wov] }\end{array}$ \\
\hline Atherstone, Warwickshire & $\begin{array}{l}\text { BEneg [eint] } \\
\text { Doneg [dount] x2 } \\
\text { WILLneg [wount] }\end{array}$ \\
\hline Cannock, Staffordshire & $\begin{array}{l}\text { Doneg [dひnə] (x 2) } \\
\text { BEneg [eint] }\end{array}$ \\
\hline Lichfield, Staffordshire & $\begin{array}{l}\text { BEneg [Inə] for X3 } \\
\text { Doneg [dひnə] } \\
\text { wouLDneg [wचdnt] }\end{array}$ \\
\hline Eccleshall (Mid Staffordshire) & $\begin{array}{l}\text { BEneg [Inə] } \\
\text { WouLDneg [wひnə] }\end{array}$ \\
\hline Wellington (Shropshire) & WouLDneg [wชnə] \\
\hline Coalbrookdale (Shropshire) & wouLDneg [WInə] \\
\hline
\end{tabular}


Appendix 2

Raw tokens of negation from the Survey of English Dialects locations closest to the Black Country

\begin{tabular}{|c|c|c|c|c|c|c|}
\hline $\begin{array}{l}\text { FORM (ALL } \\
\text { PERSONS } \\
\text { COLLAPSED) }\end{array}$ & $\begin{array}{l}\text { St } \\
11\end{array}$ & Wo1 & Wo2 & Wa2 & Sa11 & St8 \\
\hline BEneg & $\begin{array}{l}\text { beI } \\
\varepsilon I\end{array}$ & EInt & $\begin{array}{l}\text { e:nt } \\
\text { be:nt } \\
\text { (older) } \\
\text { a,nt } \\
\text { (older) }\end{array}$ & ent & $\begin{array}{l}\text { amt } \\
\text { Inə } \\
\text { anə } \\
\text { binə }\end{array}$ & $\begin{array}{l}\text { beInt } \\
\text { eInt }\end{array}$ \\
\hline $\begin{array}{c}\text { BEneg } \\
\text { emphatic }\end{array}$ & $\begin{array}{l}\varepsilon I \\
\text { Inə } \\
\text { ('older') }\end{array}$ & & & & & \\
\hline BEneg past & $\begin{array}{l}\text { wo: } \\
\text { wo:t }\end{array}$ & wa:nt & wa:nt & wə:nt & wDnə & wo:nt \\
\hline WILL neg & $\begin{array}{l}\int a n t \\
\int 3: t n\end{array}$ & wpont & wonə & $\begin{array}{l}\text { wont } \\
\text { ont }\end{array}$ & Janə & wount \\
\hline SHALL neg & $\begin{array}{l}\text { Ja:nt } \\
\int \jmath: t ə n\end{array}$ & Ja:nt & Janə & Jo:nt & Janə & fa:nt \\
\hline HAVE neg & $\begin{array}{l}æ: \\
\text { æ:t }\end{array}$ & $\begin{array}{l}\text { avnt } \\
\text { e:nt } \\
\text { eInt } \\
\text { e:n }\end{array}$ & $\begin{array}{l}\text { anə } \\
\text { a:nt }\end{array}$ & $\begin{array}{l}\text { Ent } \\
\text { aznt }\end{array}$ & anə & $\begin{array}{l}\text { avnt } \\
\text { aznt }\end{array}$ \\
\hline WILLneg & $\begin{array}{l}\text { fa:nt } \\
\text { wornt } \\
\text { wor }\end{array}$ & wpont & wonə & $\begin{array}{l}\text { wont } \\
\text { ont }\end{array}$ & wชnə & wornt \\
\hline MUSTneg & mosnt & musnt & musnt & musnt & $m \wedge n ə$ & $\begin{array}{l}\text { mos } \\
\text { not } \\
\text { monə }\end{array}$ \\
\hline CANneg & $\begin{array}{l}\text { ka:nt } \\
\text { kJ: }\end{array}$ & $\begin{array}{l}\text { ka:nt } \\
\text { ka: }\end{array}$ & $\begin{array}{l}\text { kpnə } \\
\text { kanə } \\
\text { ka:n }\end{array}$ & ka:nt & kanə & $\begin{array}{l}\text { kJ:n } \\
\text { kanə }\end{array}$ \\
\hline DOneg & $\begin{array}{l}\text { dount } \\
\text { dont }\end{array}$ & $\begin{array}{l}\text { dpont } \\
\text { dponn } \\
\text { dount }\end{array}$ & $\begin{array}{l}\text { donə } \\
\text { dount }\end{array}$ & $\begin{array}{l}\text { dunt } \\
\text { du:nt } \\
\text { døznt } \\
\text { dornt }\end{array}$ & $\begin{array}{l}\text { d^nə } \\
\text { donə }\end{array}$ & $\begin{array}{l}\text { dønə } \\
\text { doont } \\
\text { døznt }\end{array}$ \\
\hline DOpastneg & deI & didnt & didnə & dIdn & dIdnə & dIdnt \\
\hline
\end{tabular}

